\title{
Evaluation of Tear Film Osmolarity Among Diabetic Patients Using a TearLab Osmometer: A Facemask/ COVID-19-Induced Comment [Letter]
}

\author{
Reza Rastmanesh $\mathbb{D}^{1,2}$ \\ 'The Nutrition Society, London, UK; \\ ${ }^{2}$ The American Physical Society, College \\ Park, MD, USA
}

\section{Dear editor}

I read with interest the article by Abusharha et al. ${ }^{1}$ I would like to suggest adding two critical comments to their core conclusion. Since the authors observed that tear osmolarity is not significantly different in their small sample of enrolled diabetic participants, they suggest that "the finding may be explained by a lack of relationship between tear film parameters and diabetic severity; tear film parameters may correlate more with diabetic duration rather than severity". While their interpretations can be partly true, those discussions are subject to two major biases.

Firstly, they have not provided a table to describe characteristics of participants, and the date when the study was carried out is not given in the paper. However, calculatedly, the mean age of diabetic patients in their study is significantly higher than that of their control group $(P<0.001)$, which questions any comparison.

Secondly, if assumedly their study was carried out during the COVID-19 pandemic, then a game-changing bias has not been accounted for in their study design. Mandatory facemask wearing during COVID-19 negatively—directly or indirectly-affects the ocular surface and dry eye, and results in dry eye creation or worsening preexisting eye dryness. $^{2}$ Both basal tear production ${ }^{3}$ and reflex tearing ${ }^{4}$ are tightly associated with tear osmolarity in a bilateral fashion. Since drastic between-individual differences exist in terms of facemask wearing, ${ }^{5}$ the severity and/or degree of facemask-induced eye dryness would be expected to be different in their nonrandom enrolled participants.

With these in mind, it is possible that lack of relationship between tear film parameters and diabetic severity, and pronounced association with diabetic duration would be most likely due to the (i) significantly higher mean age of diabetic patients than controls, not necessarily diabetes duration per se, and (ii) unmeasured/nonadjusted tear secretion in their study design. These imply that their conclusion could be either an artifact, or a genuine observation; or, association in some patients might be more pronounced, while in some patients, associations might be attenuated.

These comments apply not only to the paper by Abusharha et al, ${ }^{1}$ but more generally to "all" studies investigating dry eye in diabetic patients since the appearance of COVID-19. A full citation of all the publications is beyond the scope of this letter, due to the space limits, but can be made available by the author on request.
Correspondence: Reza Rastmanesh \#6, Physicians Building, Sarshar Alley, Vali Asr Street, Tajrish, Tehran, 196|835555, Iran

Email r.rastmanesh@gmail.com 
- I take this opportunity to introduce, for the first time, a hidden bias entitled "Facemask/COVID-19Induced Bias" in ocular investigations dealing with dry eye and related diseases/parameters (such as lipid eye thinness).

- To control for such a confounding effect, I further suggest that there is an urgent need to develop and validate a specific questionnaire to quantify facemask-induced eye dryness (per type/duration/per steadiness, etc) to be used in real world settings.

I hope that this comment will trigger an enthusiasm for development of novel tools to measure eye dryness quantitatively in real world settings during the COVID-19 pandemic.

\section{Disclosure}

The author reports no potential conflicts of interest in this communication.

\section{References}

1. Abusharha A, Alsaqar A, Fagehi R, et al. Evaluation of Tear Film Osmolarity among diabetic patients using a TearLab osmometer. Clin Optom. 2021;13:257-261. doi:10.2147/OPTO.S325768

2. Krolo I, Blazeka M, Merdzo I, et al. Mask-associated dry eye during COVID-19 pandemic-how face masks contribute to dry eye disease symptoms. Med Arch. 2021;75(2):144-148. doi:10.5455/ medarh.2021.75.144-148

3. Dogru M, Katakami C, Inoue M. Tear function and ocular surface changes in noninsulin-dependent diabetes mellitus. Ophthalmology. 2001;108(3):586-592. doi:10.1016/S0161-6420(00)00599-6

4. Saito J, Enoki M, Hara M, et al. Correlation of corneal sensation, but not of basal or reflex tear secretion, with the stage of diabetic retinopathy. Cornea. 2003;22(1):15-18. doi:10.1097/00003226200301000-00004

5. Prichard EC, Christman SD. Authoritarianism, conspiracy beliefs, gender and COVID-19: links between individual differences and concern about COVID-19, mask wearing behaviors, and the tendency to blame China for the virus. Front Psychol. 2020;11:3130. doi:10.3389/ fpsyg.2020.597671

Dove Medical Press encourages responsible, free and frank academic debate. The content of the Clinical Ophthalmology 'letters to the editor' section does not necessarily represent the views of Dove Medical Press, its officers, agents, employees, related entities or the Clinical Ophthalmology editors. While all reasonable steps have been taken to confirm the content of each letter, Dove Medical Press accepts no liability in respect of the content of any letter, nor is it responsible for the content and accuracy of any letter to the editor.

Clinical Ophthalmology

\section{Dovepress}

\section{Publish your work in this journal}

Clinical Ophthalmology is an international, peer-reviewed journal covering all subspecialties within ophthalmology. Key topics include: Optometry; Visual science; Pharmacology and drug therapy in eye diseases; Basic Sciences; Primary and Secondary eye care; Patient Safety and Quality of Care Improvements. This journal is indexed on PubMed
Central and CAS, and is the official journal of The Society of Clinical Ophthalmology (SCO). The manuscript management system is completely online and includes a very quick and fair peer-review system, which is all easy to use. Visit http://www.dovepress.com/ testimonials.php to read real quotes from published authors. 